\title{
Communication Strategy of Relationship Chat Account Manager in Managing the Follower
}

\author{
http://dx.doi.org/10.25008/jkiski.v6i1.363
}

\author{
Anna Gustina Zainal ${ }^{1}$, Toni Wijaya ${ }^{2}$, Andy Corry Wardhani ${ }^{3}$ \\ ${ }^{1,2,3}$ Department of Communication Studies, Lampung University \\ Jl. Sumantri Brojonegoro No. 1 Gedung Meneng, Bandar Lampung - Indonesia \\ ${ }^{*}$ Corresponding author's email: anna.gustina@fisip.unila.ac.id
}

Submitted: February 16, 2021, Revised: March 24, 2021, Accepted: April 21, 2021

Accredited by Kemristekdikti No. 28/E/KPT/2019

\begin{abstract}
Each social media account created by users has its own purpose and meaning,. That is to attract the sympathy of the audience, Just like in real world, humans cannot live without socializing and interacting each other. This research was designed to find out the communication strategy of social media account managers in managing followers. This study used an interactional communication strategy with qualitative descriptive method. The results showed that the communication strategy used to manage the "chat relationship" account is the interactional communication strategy. This model had been used because followers have different backgrounds, knowledge, experiences, and cultures that affect each person in interpreting message. There are many factors as key success to running an online-based business through social media "relationships chat" account in order to increase followers loyalty in accordance with the strategy adopted by the account managers. Several management strategies had been applied such as a presentation to the audience, audience segmentation, consistency in providing entertainment to the audience, consistency of the characteristics and features needed, constantly looking for the latest entertainment innovations, communicating directly with consumers to support activities, and creating cooperation between account managers are being the key success to gain sympathy and loyalty from followers.
\end{abstract}

Keywords: Communication strategy, followers, line, loyality, social media

\section{Introduction}

According to (Utami, Lestari, \& Putra, 2015), as much as 90 percent of Indonesia people use internet access for social media. New media era makes social media as main option to connect with other people in internet (Mangold \& David, 2009). LINE is one of newest social media which is mostly used by digital natives. As generation who fluently uses technology, digital natives use LINE as communication media when social needs are separated by geographic location (Gill, 2019).
Usage of LINE continuously can make a habit eventually change into culture in communication. In this study, digital native communication culture caused by usage of LINE is interesting to research.

Currently, the dissemination of information is easy, supported by the advance of technology especially the internet. In addition, communication can easily be conducted thanks to the presence of social media. According to Shirky (Fuchs, 2014), social media and social software are tools to 
improve the ability of users to share, cooperate with other users and take collective action, which are all outside the institutional or organizational framework.

There are many forms of social media, for example, WhatsApp, Instagram, Snapchat, Facebook, Line, and so on. Social media interacts using techniques that are very easy to access and facilitate publication to users (Kaplan M., 2010). According to Mayfield (Razmerita, Kircherner, \& Nabeth, 2015), social media has various indicators. First, participation that social media encourages contribution and feedback. Second, openness where almost all media platforms are open for feedback and participation. Third, encouraging users to vote, comment, and share information. Fourth, communication on social media communication takes place in two directions, and can be distributed to a wide audience easily and quickly. Fifth, forming communities by providing opportunities to communicate effectively with each other according to their goals. Sixth, connecting one to another because almost all social media can be connected to each other, such as making links on sites, other sources and people (Nasution, 2016). These six indicators, if synergized properly, will create organizational communication in an online forum to be effective.

Based on a report entitled "Essential Insights Into the Internet, Social Media, Mobile, and E-Commerce Use Around the World" published on January 30, 2018, of Indonesia's total population of 265.4 million, 130 million are active users of social media with penetration rate of 49 percent. One of the applications that is widely used by the Indonesians is Line. Users who claim to frequently access Line make up 33 percent of the total number (Ali, 2019).

Nowadays, social media can be operated by anyone from teenagers to the elderly, thus making social media a strategic platform to explore various needs and necessities of life. One of them is in business activities or better known as e-commerce activities. Basically, social media created by users have their own goals and uses, namely to attract the sympathy of the public, just like in real life, humans cannot live without socializing and interacting with others. Moreover, in online-based business activities, the goal is to reach the sympathy of the audience to get interested in the products or services offered.

The rapid growth of e-commerce market share in Indonesia cannot be doubted anymore. With the number of internet users reaching 63 million or around 30 percent of the total population in Indonesia, the e-commerce market is a gold mine that is very tempting for some people who can see the potential going forward. This growth is supported by data from kominfo.go.id which stated that the value of e-commerce transactions in 2017 reached Rp. 130 trillion.

Line is a new form of Instant Messenger whose function is to conduct communication where each user does not use credit, but rather a network or internet connection (Karmila, 2018). The Line application can also be referred to as a social networking application because there are timeline feature as a place to share status, voice messages, videos, photos, contacts, and location information. Furthermore, the ongoing communication is not just to convey information or exchange information but also to create and maintain relationships.

Many advantages offered by Line @ can be utilized by its users, ranging from shop owners, restaurants, organizations, to part-time workers. The most important advantage is direct integration with Line, where contacts that are stored in a line account will automatically be stored in the Line @ account. Furthermore, Line@ users can send broadcast messages to their entire contact list, complete with an auto-reply function where replies can be given automatically, including those based on certain keywords.

Line@ also allows businesses to distribute promotional campaign coupons directly through the Line@ platform, just like Line, Line@ also has a timeline feature so that business people can display the latest information to be conveyed in a unique format. There are also statistical features so that Line@ account owners can manage their accounts optimally. The author chooses the ecommerce application Line @ as the object of research in accordance with the data described above, because of e-commerce development in Indonesia and teenage interest in Line social media. The researcher is interested in the development of the online-based business that is Relationship Chat account. This account is one of e-commerce accounts in Line Indonesia 
that have many followers, mostly kids and teenagers.

Relationship chat is an entertainment account created with the aim of inspiring followers from the stories of others, in the form of a conversation screenshot, romantic, funny and sad pictures, and quotes that form a meaning that can ultimately be understood as an interesting story to read and the story could be an inspiration for his followers. The aim of carrying out its activities is to gain loyalty from consumers.

In addition to followers, consumers also included advertiser accounts (Tariq, Mehboob, \& Khan, 2012), which collaborated with Relationship chat accounts (To be able to manage consumers (in this case followers), an appropriate communication model is needed between the account owner and his followers. This is important to do because the competition between entertainment accounts is quite high.

Economic activity in the information society (digital era) is referred to as digital capitalism (Mosco, 2009). Digital capitalism will form social relationships and increase the capacity of communication network. According to Mosco, this is the same as increasing the ability of capitalist to get power and acquire more profit. Digital capitalism can do through convergence practices. Convergence is understood as a form of integration that occurs in the mass media, computers, and telecommunications.

Convergence can occur in the communications sector in the form of media convergence (Grewal \& Coleman, 2019). One form of media convergence is media diversification. Media diversification is defined by (Lase \& Rio, 2014) as the expansion of media companies which are carried out diagonally or expand the company's business to new business fields, for example, into the new media field.

Diversification, according to (Mosco, 2009), is classified in the form of horizontal integration, because the occurrence of media expansion to the non-profit field or opposite is a form of integration horizontally (Appel, Grewal, \& Hadi, 2020). Media diversification is something important for media companies to remain viable in today's new media market. Merger and alliance formation with other companies will have an impact on the efficiency of production costs. Besides, diversification has the main objective to increase the company's profit and expand or gain new market so that it will expand the power and influence of the company in the media market (Lase \& Rio, 2014).

The novelty in this research is the use of strategy concepts and communication models to discuss the use of a form of social media line, namely, relationship chat in increasing the number of followers. This study aims to determine the communication strategy of line social media account manager in the strategy of managing consumers.

\section{Theoretical Framework}

The communication process starts from the mind of the person who will convey the message or information. What is thought is then symbolized (symbol), both in the form of speech or picture cues. The next process is through transmission in the form of media and intermediaries or channels such as telephone (Susanto, 2017), letter, orally, etc., then the message delivered arrives at the recipient. In the recipient, he first receives the message, then tries to interpret the message (decode) and finally understands the contents of the message (Suardi, 2016). The response or reaction from the recipient of the message to the sender of the message is feedback.

The requirements that need to be considered by a communicator are as follows: (1) Having high credibility for the communication; (2) Having communication skills; (3) Having extensive knowledge; (4) Having a good attitude towards the communicant. e) Having appeal. f) Having an attraction in the sense that the communicator has the ability to change attitudes or increase knowledge for or in the communicant (Cangara, 2015).

The main problem in communication and behavior models is errors in social perception caused by differences in social and cultural backgrounds that affect the process of perception, so that the communication model that is formed also changes. The communication model that occurs starts from the delivery of the message, the media used to convey the message and the recipient of the message (Mulyana, 2007). Communication Model is a process designed to represent the reality of the elements involved and their continuity, in order to facilitate systematic and logical thinking (Effendy, 2008). 
Communication is one part of human relations, both individuals and groups, in everyday life (Zainal, 2019). From this understanding, it is clear that Communication involves a number of people where one states something to others, so that who are involved in communication are those humans. Communication starts from an idea that is in someone (Kaplan M., 2010), the idea is processed into a message and sent through certain media to others as recipients.

Recipient of the message has understood the message from the sender of the message. By receiving a response from the recipient of the message (Kim, LaRose, \& Peng, 2009), the sender of the message can assess the effectiveness of the message sent. Based on that response, the sender can find out whether the message is understood and the extent to which the message is understood by the person receiving the message. While the communication pattern, according to (Riyanto, 2016), is a process designed to represent the reality of the elements involved and their continuity, in order to facilitate systematic and logical thinking.

This study uses an interactional communication model. Interaction communication model is a communication model that describes two-way communication (Saraswati, 2018). Generally, the interaction communication model is used in new media, such as the internet or modern communication media. Interactional communication model or also called convergent communication model is a communication model that has similarities with the transactional communication model because they are two-way communication models.

However, the interactional communication model is mostly used for such as the internet. One of the communication models included in the interactional communication model is the Schramm communication model (Lamberton \& Stephen, 2016). Experts have introduced various communication models in an effort to describe and explain the communication process and various factors that influence the flow and effectiveness of communication.

In the interactional communication model there are communication components that support the ongoing communication process. These components are as follows (1). The source or sender of the message - the person who initiated the message, (2). Encoder - the person who sent the message. Encoder and decoder are the same person as the source. The source acts as an encoder when sending messages and acts as a decoder when receiving messages, (3). Decoder - the person who received the message. Decoder and encoder are the same person as the recipient of the message. The second source decodes the message then sends another message, encodes the message, and sends it to the first source, (4). Message recipient - the person who received the message, (5). Message information sent during the interaction process, (6). Feedback - the decoder forms the second message after receiving the first message, (7). Disturbances - various things that can interfere with the course of the communication process and can occur at every stage of communication, (8). Barriers - various things that hamper the course of the communication process such as physical barriers, mechanical barriers, semantic barriers, and others.

There is another important element or part in the concept of interactional communication which is marked by the existence of a person's field of experiences, crocodiles or descendants that can influence the ability to communicate with others. Each communication participant brings a unique and unique experience in every communication behavior that can affect the communication that occurs.

In the world of communication, the technique of delivery or influence can be seen from two aspects, namely: according to the way it is implemented and according to the form of its content. This can be further elaborated, that the former merely sees the communication in terms of its implementation by removing attention from the content of the message (Zang, Trusov, Stephen, \& Jamal, 2017). While the latter, namely seeing the communication in terms of the form of a statement or the form of the message and the intent contained. Therefore, according to the method of implementation, it can be realized in two forms, namely redundancy (repetition) and canalizing. While the second, according to its content form, is known as techniques: information, persuasive, educative and coercive (Arifin, 2003). 


\section{Material and Methodology}

The research used qualitative method with descriptive approach, because the qualitative method is able to explain phenomenon through data collection obtained during interviews. According to (Kriyantono, 2006), a qualitative approach goal is to explain phenomenon profusely through deep data collection. This study does not prioritize population size or sampling. If the data collected is deep and can explain the phenomenon under study, then there is no need to look for other sampling. This research emphasizes the problem of depth (quality) of data rather than the amount (quantity) of data. According to (Moleong, 2007), descriptive research aims to describe the complex social realities that exist in society.

The informant or subject in this study is the owner of a Relationship Chat account, consisting of only one person, namely Dea Yuni Fahleni, who is the owner and leader in managing the relationship chat account, and another subject involved in this study is the admin of the account relationship chat consisting of two people, namely Suci Aprilia Ningsih and Dita Ramadani, the admin in this account are the people whose job is to operate account activities whether it's posting, relationship with the advertiser's account, or others.

Data collection techniques used in this study are in-depth interviews, observation, literature study, and documentation. The data analysis process was carried out through data reduction, data presentation, and data verification.

\section{Result and Discussion}

Social media as a medium for virtual interaction that is so large, complex, and well connected, makes it easier for everyone who uses social media to find colleagues and other accounts by simply searching and typing the account name in the search field, but to provide useful information as complete as possible for the account created, the account owner can indicate the account with a photo or supporting information, such as a profile photo and a homepage photo.

According to the owner of the Relationship Chat account, such management can help visually attract the account to the interest of followers. The message to be conveyed to the audience as a communicant is a characteristic of the Relationship Chat account (Widodo, 2016) which can be shown through consistency of use, be it the use of profile photos, home photos, chat room colors, and chat selection on the selected posts, which are the clearest /good quality capture, the most readable, and the most representative of teen chat.

\section{Prioritizing coordination between fellow managers}

The most important factor outside how the account manager manages external stakeholders is how the account previously had a solid internal team, to create an effective and pleasant working atmosphere, so that in the end account mobility can always be wellcoordinated and according to plan. According to the owner of the Relationship Chat account, coordination and good communication between account managers is a very important factor in running an online-based business.

The audience is in the form of perception by assuming that the admin-admin relationship chat is humble and friendly to their followers so that a good image is formed of the account, and with this, it is necessary to form cohesiveness in the team first, and in the end, followers, as communicants feel a comfortable level of Relationship Chat accounts are higher and create loyalty, which is measured from the interaction created in each post which remains consistent from followers.

\section{Special Treatment of Loyal Followers and Advertisers}

As an account that has virtual consumers, this is certainly not much different from companies that have consumers in the real world, special treatments that are occasionally given to consumers are needed, namely by holding quizzes with prizes, this is recognized by the account, the owner can have a pleasant effect on followers and a beneficial effect on a Relationship Chat account, so that such approaches can attract more attention from followers who are tempted by the offer of gifts given.

\section{Implementation of Advertising Cooperation Regulations}

It is almost certain that business accounts created on social media aim to gain economic benefits, the more existing social media, the greater the possibility of benefits, and most 
new social media accounts are routinely looking for other accounts that have more followers. To work together to offer their products and services, the goal is to make these accounts more widely known in the community, according to the owner of the Relationship Chat account. The more accounts that use advertising collaboration, the account owner must be more selective in choosing, because of the circumstances. This is often used by irresponsible people to commit fraud.

\section{Managing Ads to Be More Effective}

The number of ad posting must be limited so that the presence of advertising messages does not interfere with the focus of followers in enjoying chat story posts provided by the Relationship Chat account. The message in the advertisement even though it contains products or services from other accounts, what kind of content the ad message can be a measure of the quality of the account or not. Therefore, before the ad is posted, the owner and admin double-check and edit the ad caption if it needs to be edited, and provide the hashtag \#relationshipchat as a marker for the ad to advertise in a relationship chat account, so that communicants can understand the ad clearly and the ad function can be more effective.

\section{Post and Ad Management}

Posting activities is indeed the main obligation of the Relationship Chat account, especially because this account is an entertainment account that sells interesting stories to its followers and does not sell products or services that are real, but according to the owner of the Relationship Chat account, post and ad management, It is also something that needs to be realized and important because the comfort of the followers must also be prioritized. Post messages are given to followers as communicants are diverse, this is always treated as a variation and creates an atmosphere that is not boring to followers, for example in a day a relationship chat account posts $6 \mathrm{x}$ chat stories, the six posts have different themes. Likewise, with advertisements, which are limited to $2 \mathrm{x}$ a day, the two advertisements sell different products or services, the effect desired by the owner and admin as communicators are to attract new followers and create comfort for existing followers.

\section{Techniques in Choosing a Post Theme}

In managing social media accounts, which offer entertainment, according to the owner of the Relationship Chat account, consistency is needed in presenting posts, such as consistently presenting the themes raised, so that they become a separate character or characteristic of the account, for the Relationship Chat account itself, the theme of the chat that is posted is in accordance with their identity, namely chats in a relationship, both family relationships, friendship, romance, and others that contain certain meanings that inspire readers / followers when reading it.

Last but not least, in managing consumers, interacting directly in response to followers who want to convey criticism and suggestions, by replying to the chat they provide, in order to form a good personal closeness between the account manager and their followers, what is presented by the manager, can not only be enjoyed by good followers, but also can increase the closeness and good understanding of followers of the posts provided by the Relationship Chat account, and of course, it can lead to two-way communication, which incidentally not all social media implement the same thing as a Relationship Chat account.

\section{Manage Post Messages Effectively}

According to the owner of the Relationship Chat account, in winning the competition, a good service strategy is needed in the form of serving posts according to the wishes of the followers and providing good service to followers by providing good information and not containing negative messages. As with the previous explanation, personal closeness is a top priority for account managers to build closeness with followers, the closeness in question is always creating two-way communication with followers, by responding to and interacting directly in the comments column of posts or directly chatting personally with Relationship Chat account managers.

\section{The technique for Packaging Message Elements in Posts}

As an entertainment account whose activities are to post interesting stories from a conversation/chat which are packaged in the form of screenshots, of course, the main factor in the attractiveness of this account is the 
content of the stories that are adopted and packaged in such a way. According to the owner of the Relationship Chat account, with the use of captions/sentence descriptions of interesting posts, the identity of the hashtag that is always used, and the use of emoticons as needed, can make the message that is given in a post to the communicant which in this case is the followers more attractive and digestible well by the followers of the Relationship Chat account and the intent of the post can be conveyed effectively to the communicant.

\section{Account manager communication model}

Social media has changed the world. Levels of communication merged into one container called a social media. The rise of many consequences must also be wary of, in the sense of social media opens up the opportunity of each individual involved in it to issue his opinion freely (Watie, 2011). The use of social media has increased sharply in line with the development of internet users in Indonesia. Not only in Indonesia, this phenomenon can be said to occur in almost all countries in the world. No wonder then that the use of social media is increasingly widespread. If in the past social media only functioned as a platform to establish network and form friendship, so along with the increase in the number of social media users and their activities in it, the function of social media has also expanded.

Modernization has really changed the habits of our society. If previously information dissemination was only done through print and electronic media, now information can quickly be spread well through the internet, especially through social networks. In fact, social media has formed public spaces, where people are free to express their opinions or activities. Social media is a broad and complex container of communication interaction, message exchange activities in it are so diverse, that it automatically makes social media contain many scientific aspects, especially scientific aspects in the field of communication, Relationship chat accounts are one of the social media accounts that have many aspects. This communication is measured by the various activities in it. This is relevant to the strategies used by the account manager to gain loyalty from his followers which has been described in the previous chapter.
A Relationship chat account is an account initiated by a 15 -year-old high school student and created using the Line@/OA/Official Account application, a business application issued by Line social media, whose primary purpose is to serve as a small-scale onlinebased business media and secondary, the business categories offered by Line @ are as follows, professional, restaurant and cafe, trade and retail, health / beauty care, schools and universities, entertainment venues, tourist attractions, lifestyle, health and medical, nonformal education, travel and tourism, meeting halls or show venues, motor vehicles, public transportation or rental places, gas stations / telephone shops / internet cafes, legal and accountant services, insurance and financial banking, places of worship, communities and mass organizations, children's play groups, other local businesses, businesses and organizations, brands / products, magazines and newspapers, films, music, sports, television, websites and blogs (http: // line @. id).

Determination of the strategy in managing consumers and accounts used by managers can be said to be very effective in gaining sympathy from the public, but apart from the strategies implemented, the thing that needs to be understood is the accuracy of the owner / Relationship chat account owner in seeing opportunities as a very important factor. This account picks up teenage love stories, school stories, friendship stories, family stories, which contain elements of humor, confusion, and other elements that are packaged in the form of captured chats, along with the original chat from the donors.

The fact is that followers who are actually children at the age of 13-18 years in the technological era like now, are in a position of self-introduction, are looking for an environment that suits their character, or in their daily language, are in infancy (puberty). They are likely at the age believed to consume social media the most, according to the facts the authors describe in the first chapter. That is what the author understands as the main key to why a relationship chat account has a certain close relationship" with their followers.

Apart from that, of course, now the challenge for relationship chat accounts is how the relationship chat account manager can always be consistent in giving posts that are always in demand by followers and as a 
consequence, followers can always be loyal to the account, and the audience outside the account can pay even greater attention to join in this virtual group. The three informants in this study took their respective roles to succeed in the communication model to increase the loyalty of their followers, in accordance with the observations, interviews and documentation that the author got and observed in the field. The consumer management model of communication consists of: Post emotional and psychological approaches, personal closeness to followers, personal closeness between managers, follower services, and advertising cooperation, and also account management strategies, which consist of posting packaging broadcast ad management delivered properly.

Success in running an online-based business through social media, is made especially in entertainment-type businesses such as relationship chat accounts. Increasing the loyalty of followers in accordance with the strategy adopted by the account manager lies in the form of entertainment such as what they want to present to the audience, and determine the appropriate audience segmentation. Consistency in providing entertainment to the audience, consistency with the characteristics and character of the entertainment possessed, continuing to explore and seek the latest entertainment innovations from time to time, communicating directly with consumers to evaluate activities, and creating a good working atmosphere among account managers, become the keys to the success of the account to gain sympathy and loyalty from followers.

As is known, everyone has a background in knowledge, experience, and culture that is different from one another. This background differences affect each individual in interpreting the message received. In the process of communication between account managers and followers, doing things characterizes the interactional communication model, namely: focus on encoding and decoding. Communication takes place in two directions, the concept of field of experience which is a psychological effect can help to understand the communication process.

For instance, to make communication run smoothly, skills are needed, and not everyone has the communication skills. Many people communicate only by relying on the style that is used daily. They assume the method used is correct. In this study, the selection of online social media as a medium for running an online-based business today can be said to be effective. This is in line with what (Nurhadi, 2017) said regarding social media. Many things can be utilized with this social media, but sometimes not many people take advantage of this social media any further, nothing more than media that facilitates to fill the free time of the users.

In that research study (Nurhadi, 2017) explained a number of statements about motives, experiences, and social interactions. For him, social media relating to these three studies is a unity that supports each other in the communication process. This is appropriate psychologically, when individuals communicate with others or through an intermediary (medium), a mental communication process will be developed and encourage communication actions so that it makes a unified whole in the activities of their life.

Yet if we look deeply there are still many communication mistakes that we do not know and often happen when we do a communication process. The effectiveness of a communicator can be evaluated from the angle of the extent to which these objectives are achieved. Requirements for successful communication are to get attention. If the message is delivered but the recipient ignores it, then the communication attempt will fail. The success of communication also depends on understanding the recipient's message. If the recipient does not understand the message, then it is not possible to succeed in giving information to or influencing the recipient.

\section{Strategy of managing followers}

In managing relationship chat accounts, the manager has been trying to implement several kinds of management strategies. This is done in addition to attracting new consumers as well as in order to maintain follower loyalty. Based on the results of the study, the relationship chat account owner in managing consumers is done first by grouping consumer management. It consists of management of followers and management of advertiser accounts.

After being grouped, the owner determines the communication strategy that will be used to manage its customers. In this case, the owner determines the two selected 
communication strategy techniques, namely how the presentation technique is in terms of its implementation and how the message delivery technique is based in the form of its contents.

\section{Personal Proximity to Followers}

The manager of the relationship chat account is active and does not become a passive manager in serving followers and advertisers. The manager routinely joins in the comment post room to reply questions or respond directly to followers. The relationship chat account also provides an "admin account" as a forum for followers who want to contribute chat stories that they have to post on the relationship chat account. One by one the manager will sort and provide an assessment of the chat stories contributed by followers to decide whether the chat is accepted or not. If the chat is not accepted, then the manager will provide an explanation to the follower.

\section{Personal relationship between Managers}

In an organization that has a specific purpose, it is wrong if the organization focuses on building good relations with external parties only, without paying equal attention to building a good relationship with internal parties. This is also done by the three manager accounts, which are creating a good working atmosphere by always building two-way communication, in order to create a common vision and mission in running the account.

\section{Followers Service}

The number of accounts that are present on social media Line@makes the consistency of the account come as a necessity to maintain customer loyalty. Story posting activities carried out by the account are as much as 6 times a day with the most vulnerable time to post stories once an hour and no later than 6 hours, while info / advertisements via broadcast is 1 ad per day and timeline info totaling 1 ad per day. Besides other activities such as giving away / quizzes with prizes are also routinely carried out at least $2 \mathrm{x}$ a year by the account manager to increase consumers morale especially followers to check the account timeline regularly.

\section{Advertising Collaboration}

The number of followers of relationship chat accounts dated 15 March 2019 which already reached 389,100 attracted more and more other Line@ accounts to advertise in relationship chat accounts. According to author's interview with the account owner on March 12, 2019, each month the Relationship chat account provides 60 slots for advertisements. The order is opened midmonth before every 15 th, with details of 2 slots per day, so 60 slots are spent within 30 days/1 month.

Before the end of the month, the slot for the next month is always out of order. With so many advertiser accounts coming in, Relationship chat accounts can receive 120 slots at once with 4 advertisements per day, but account managers consider the convenience of account followers who would have been distracted by the number of ads. Therefore, this could have an adverse impact on accounts such as followers blocking accounts. As a result the advertising cooperation is arranged in such a way by the manager to create a win win solution for their own relationship chat accounts and advertiser accounts. One way is to occasionally hold a quiz with prizes and raise advertising rates every month.

\section{Manage Advertising Broadcast}

Advertising is an economic source of income that must be managed properly by the account manager. This is because on the one hand the ads can bring benefits, while on the other hand the presence of advertising sometimes causes harm to the account. Ad management, in this case is not only related to financial management, but also the frequency of ad serving on the account. The frequency of these ads needs to be managed because the number of ads that are too much will disrupt followers. Likewise, an account with no or little advertising will also affect their image in the eyes of followers. Therefore, the strategy in managing advertisements must be arranged in such a way as to form a win win solution that is profitable for Relationship chat accounts and those who advertise.

Emotional and Psychological Approaches in posting

Account Relationship chat is an entertainment account that provides 
inspirational values to followers through the stories of other people presented in the form of conversations/chats that are screenshot and posted on the account homepage. Of course, the contents of messages delivered by the account manager, are very decisive. The attractiveness of the story is very important, because the themes and contents of the chat screenshoot message chosen by the account manager must be appropriate and able to attract and represent the mood of the reader, who incidentally is children and adolescents.

\section{Post Packaging}

Posting packaging is the technique of managing the message elements contained in posting Relationship chat accounts. Hence, the message posts become more interesting. The purpose of the post is to reach the consumer precisely and maximally so that the message contained in the post becomes more interesting and raises desired effect. The message elements contained in the post include:

\section{Account Display}

The home page display of the account used by Relationship chat subsequently with the targeted segmentation that is young people and teenagers. The appearance of this account has been adjusted starting with the use of the account profile photo, account background photo, and the chatroom background colors that is light green, which is considered to represent the characteristics of teenagers and young people. The appearance of the account homepage that functions as the home account, if seen at a glance by new followers, can bring its own characteristics uniquely to the account.

\section{Display Posts}

Almost all the contents of the posts that have been provided by the account manager contain the theme of a relationship and social interaction. Following is the account which is in accordance with the name of the account, namely "Relationship chat". The main theme presented is in the form of a chat theme which concerns not only a love affair of young people, but also the relationship of mother and child, the relationship of siblings etc. Thus, it contains its own positive and inspiring values, which present not only themes of love, but also themes of humor, sadness, confusion, and others.
Most of the contents of the message are displayed in the form of chat screenshots. The posting, of course, uses elements of message management with its own characteristics set by the account manager, including: (a). The theme used must be clear and in accordance with the contents of the screenshot; (b). The plot of the story presented must be clear; (c). Fill in the message not making it up (Only Real Chat); (d). The contents are not contain message that violates the rules of the norms adopted in social life, for example: pornography, SARA, and others; (e). Consistent use of wallpapers, as a form of comfort for followers to follow the storyline.

\section{Number of Posts}

As an entertainment service provider, consistency in posting interesting inspirational stories is the key to maintaining followers' loyalty, Relationship chat account currently posts chat stories at least 6 times a day and dozens of posts per day at weekend. Considering a few months ago a Relationship chat account posted circa 20 times a day, however it was less effective. Because followers interactions to likes, comments and sharing posts tend to be minimal. Therefore, the number of posts is limited to about $6 \mathrm{x}$ on workdays and 11-12x on weekends by sorting chat stories that are most preferred by followers. Similar to posting, advertisements are also limited to only $2 \mathrm{x}$ a day, broadcast advertisements and timeline ads, in order not to disturb followers.

\section{Use of Caption that are concise and relate to the theme}

The use of captions / sentences that are brief, concise, appropriate to the theme, and packaged attractively coupled with the use of good language, makes the stories more attractive to followers.

\section{Consistent use of Hastags and accentuates the account's characteristic features}

The consistent use of hashtags/hash marks that highlight the characteristics of this account is done as a sign in the meta data of a social media platform. This serves as a sign to facilitate followers for searching a theme or a topic, so that other people who want to find a particular topic can find it by simply searching through the hashtag. One characteristic of hashtags that is always used by Relationship 
chat accounts is \#relationship chat. The hashtag realtionshipchat has been known as one of the characteristics of a relationship chat account and is copyrighted.

\section{Use of Emoticons as Necessary}

Emoticon is a combination of two words in English, which is emotion means emotion and icon means symbol. Emoticons are symbols used to describe human facial expressions that contain emotions or feelings in the form of messages or writing. The use of emoticons in social media as an emotional representation of an account or someone on a topic or theme. The use of emoticons in the Relationship chat account aims to draw deeper emotions from the readers, so that the message in the post can be conveyed to the maximum communicant/consumer.

The implementation of follower management strategies that have been done by relationship chat account managers have been considered effective to increase the number of followers. However, managers in social networking relationship chat accounts must have been innovative in order to improve services for their consumers. Because without innovations in account management, followers will feel bored and relationship chat accounts will be unable to compete with similar accounts. For all of those reasons, managers of social networks need to make regular improvements to the site so that the site does not stagnate when users continue to grow. Increasing capacity and development ofthe site is important to improve customer service.

\section{Conclusion}

Based on the results of the research and the results of the researcher's analysis regarding how the account manager's strategy is to increase follower loyalty on the Relationship Chat account on the Social Media Line, the conclusions that can be drawn are as follows:

(1). Selection of the right audience segmentation and the suitability of messages to audience needs are the most basic things that Relationship Chat accounts always do;

(2). Account Relationship Chat always emphasizes the personal closeness between the account manager and his followers, and also emphasizes the closeness between fellow managers in carrying out all account activities, to continue to foster trust and loyalty from followers.

(3). Research related to the use of relationship chat accounts in social media lines in increasing follower loyalty is seen from other aspects of communication can be done by taking different research loci

\section{Reference}

Ali, N. N. (2019). Analisis Faktor Pemilihan Media Sosial Line di Kalangan Remaja Kota Bandung. Jurnalisa, 5(1), 91-105.

Appel, G., Grewal, L., \& Hadi, R. (2020). The future of social media in marketing. $J$. of the Acad. Mark. Sci. 48, https://doi.org/10.1007/s11747-01900695-1, 79-95.

Arifin, A. (2003). Ilmu Komunikasi : Suatu Pengantar Ringkas.. Jakarta (ID): PT. RajaGrafindo Persada.

Cangara. (2015). Pengantar Ilmu Komunikasi. Cetakan Kedua. Jakarta (ID): PT RajaGrafindo Persada.

Effendy, O. (2008). Ilmu Komunikasi Teori dan Praktek. Bandung (ID): Remaja Rosdakarya.

Fuchs, C. (2014). Social Media a Critical Introduction. Los Angeles: Sage Publication, Ltd.

Gill, A. (2019). The future of social media in marketing. Journal of the Academy of Marketing Science, 48, 79-95.

Grewal, L., \& Coleman, N. (2019). When posting about products in social media backfires: The negative effects of consumer identity-signaling on product interest. Journal of Marketing Research, 56(2), 197-210.

Kaplan M., H. M. (2010). Users of the world, united The challenges and opportunities of social media. Business Horizons, $53(1), 61$.

Karmila. (2018). Pemanfaatan Media Sosial Grup Messenger Line Di Kalangan Mahasiswa Dalam Mendapatkan Informasi Perkuliahan (Studi Pada Mahasiswa Ilmu Komunikasi Fakultas Ilmu Sosial Dan Ilmu Politik Universitas Syiah Kuala). Jurnal Ilmiah Mahasiswa Fisip Unsyiah, 538-548.

Kim, J., LaRose, R., \& Peng, W. (2009). Loneliness as the cause and the effect of problematic internet use: The relationship between internet use and psychological 
well-being. Cyberpsychology \& Behavior, 12(4), , 451-455.

Kriyantono, R. (2006). Teknik Praktis Riset Komunikasi: Disertai Contoh Praktis Riset Media,Public Relations, Advertising,Komunikasi Organisasi,Komunikasi Pemasaran. . Jakarta (ID): Kencana Prenada Media Group.

Lamberton, C., \& Stephen, A. (2016). A thematic exploration of digital, social media, and mobile marketing research's evolution from 2000 to 2015 and an agenda for future research. Journal of Marketing, 80(6),, 146-172.

Lase, F., \& Rio, A. (2014). Ekonomi dan diversifikasi media massa. . Jurnal Interaksi, 15-23.

Mangold, W., \& David, J. F. (2009). Social Media: The New Hybrid Element of the Promotion Mix. Business Horizons, 52(4), 357-365.

Moleong. (2007). Metodologi Penelitian Kualitatif Edisi Revisi. Bandung (ID): P.T Remaja Rosdakarya.

Mosco. (2009). The Political Economy of Communication (2nd ed.). London: Sage.

Mulyana, D. (2007). Ilmu Komunikasi Suatu Pengantar. Bandung (ID): PT Remaja Rosdakarya.

Nasution, H. (2016). Perilaku Remaja Pengguna Media Sosial Blackberry Messenger, Line Dan Whatsapp Dalam Perspektif Gender (Kasus Siswa SMA Negeri 3 Medan). Bogor: Institur Pertanian Bogor.

Nurhadi, Z. F. (2017). Model Komunikasi Sosial Remaja Melalui Media Twitter. Jurnal ASPIKOM, 3(3), 539-549.

Razmerita, L., Kircherner, K., \& Nabeth, T. (2015). Social Media in Organizations : Leveraging Personal and Collective Knowledge Processes. Taylor and Francis, 1-49.

Riyanto. (2016). Media Baru, Visi Khalayak Aktif Dan Urgensi Literasi Media. Jurnal Komunikasi Ikatan Sarjana Komunikasi Indonesia, 1(02), 90-96.

Saraswati, M. (2018). Social Media and the Political Campaign Industry in Indonesia. Jurnal Komunikasi Ikatan Sarjana Komunikasi Indonesia, 3(1). https://doi.org/10.25008/jkiski.v3i1., 124.
Suardi. (2016). Antara media sosial dalam komunikasi politik. Jurnal Risalah, 27(2), 82-86.

Susanto, E. (2017). Media Sosial Sebagai Pendukung Jaringan Komunikasi Politik. Jurnal ASPIKOM, 3(3) https://doi.org/10.24329/aspikom.v3i3.12 3, 379 .

Tariq, W., Mehboob, M., \& Khan, M. (2012). The Impact of Social Media and Social Networks on Education and Students of Pakistan. International Journal of Computer Science Issues, 9(4), 407-411.

Utami, A., Lestari, M., \& Putra, A. (2015). Communication Culture Change In New 22 Media Era (Virtual Etnhography Studies about Usage of Line By Digital Natives). EProceeding of Management, 2(3), 4042-4050.

Watie, E. (2011). Komunikasi dan Media Sosial. The Messenger, 3(1), 69-75.

West, R., \& Turner, L. (2007). Introducing communication theories: Analysis and application (3rd ed.). New York:: McGraw-Hill.

Widodo, W. (2016). Effectiveness of Line communication application as a social media on changes in tooth brushing behavior of junior high school students in Banjarmasin. . Dental Journal (Majalah Kedokteran Gigi) 49(4): , 223-228.

Zainal, e. (2019). Community Development Communication Model And Improving The Role Of Agropolitan Institutions. International Journal of Scientific \& Technology Research, 8(12), 2028-2034.

Zang, Y., Trusov, M., Stephen, A., \& Jamal, Z. (2017). Online shopping and social media: Friends or foes? Journal of Marketing, 81(6), 24-41. 